\title{
Effective Patient Blood Management
}

Öz

Son yıllarda kan ve kan bileşenleri transfüzyonunun komplikasyonları, mortalite ve morbiditeye etkileri ve maliyet üzerindeki yükleri hakkındaki farkındalık artmış ve bu, transfüzyon uygulamasına yeni bir yaklaşım gereksinimi oluşturmuştur. "Hasta Kan Yönetimi (HKY)" olarak tanımlanan bu yeni yaklaşım; doğru zamanda, doğru hastaya, doğru ürünle transfüzyon yapılmasını hedefler. Birçok diğer yerleşmiş ve neredeyse kültür haline gelmiş tıbbi uygulamada olduğu gibi, var olan transfüzyon alışkanlıklarının da bu yeni yaklaşımla değiştirilebilmesi oldukça zor olmaktadır. HKY'nin amaç, içeriği ve sonuçlarıyla ilgili artan sayıda yayına rağmen, etkin bir biçimde nasıl uygulamaya yerleştirileceği konusundaki deneyim ve çalışmalarla ilgili yayınlar sınırlıdır. Bu makalede, bu yayınlar ve HKY projesini başarılı ve yaygın olarak kullanmakta olan Avusturalya ve $A B D$ 'nin deneyim ve yöntemleri derlenmiştir.

Anahtar kelimeler: Kan transfüzyonu, liberal, restriktif, hasta kan yönetimi

\section{ABSTRACT}

Awareness about complications of transfusions of blood and blood products, their effects on mortality and morbidity and cost burden has increased in recent years which created the need for a new approach to transfusion practice. This new approach, defined as "Patient Blood Management (PBM)" aims to transfuse the right blood product to the right patient at the right time. Alteration of transfusion habits according to this new approach is quite difficult as seen in changing many established, traditional medical practices. Although there have been an increasing number of publications about the aim, context and results of PBM, there is limited studies and experience about the efficient implementation of this practice. In this article, the reports and clinical experiences of countries like USA and Australia that widely and successfully use this PBM project are reviewed.

Keywords: Blood transfusion, liberal, restrictive, patient blood management
Alındığı tarih: 20.02.2019

Kabul tarihi: 11.03.2019

Yayın tarihi: 26.07 .2019

Atıf vermek için: Tezcan B. Etkin hasta kan yönetimi. JARSS 2019;27(3):167-73.

Büşra Tezcan

Türkiye Yüksek İhtisas Hastanesi Sinhiye

Ankara - Türkiye

busraytezcan@yahoo.com ORCID: 0000-0001-8914-0234
Kan transfüzyonu, özellikle akut kanamaların neden olduğu birçok anemi tablosunda yaşam kurtarıcı bir tedavi şekli olarak uzun yıllardan beri kullanılmaktadır. Transfüzyonun klinik uygulamaya girme süreci, ilk olarak 1600 'lü yıllarda hayvanlardan insanlara yapılan denemelerle başlamış ve 1818 yılında insandan insana başarılı ilk transfüzyon gerçekleştirilmiştir. ilerleyen yıllarda savaşlar, birçok tıp alanıyla beraber transfüzyon tıbbında da oluşturduğu geniş uygulama alanına bağlı olarak hızlı gelişmelere olanak sağlamıştır. Örneğin, II. Dünya Savaşı'nda cankurtaranlar içinde askerden askere direkt uygulamayla birçok yaşam kurtarılmıştır (Şekil 1). Kan grupları, kan bankacılığı gibi keşifler de transfüzyonu modern tıbbın vazgeçilmez parçalarından biri haline getirmiş, hatta travma ve organ transplantasyon cerrahileri, kardiyak cerrahi gibi bazı kanamalı cerrahilerdeki modern uygulamalar ancak transfüzyonun olası oluşuyla gelişmiştir ${ }^{(1)}$. Bu nedenlerle hem halk hem de sağlık çalışanları arasında efsaneler yüklenmiş olan bu uygulama, 1980'li yıllardan itibaren özellikle HIV virüsünün keşfiyle ciddi anlamda neredeyse ilk kez sorgulanmaya başlanmıştır ${ }^{(2,3)}$.

Titiz taramaların rutin kullanıma girmesiyle her ne kadar transfüzyonun enfeksiyöz komplikasyonları azaltılsa da, TRIM (Transfusion Related Immunomodulation), TRALI (Transfusion Related Acute Lung Injury), TACO (Transfusion Associated Cardiac Overload) gibi komplikasyonlarla ilgili artan yayınların neden olduğu farkındalık, transfüzyon endikasyonlarının güvenilirliğiyle ilgili şüphe ve sorgulamaları devam ettirmiştir. Ayrıca gelişmiş ülkelerde yaşlanmış nüfusun artışına bağlı kan kaynakları gittikçe azalmakta, gelişmiş 


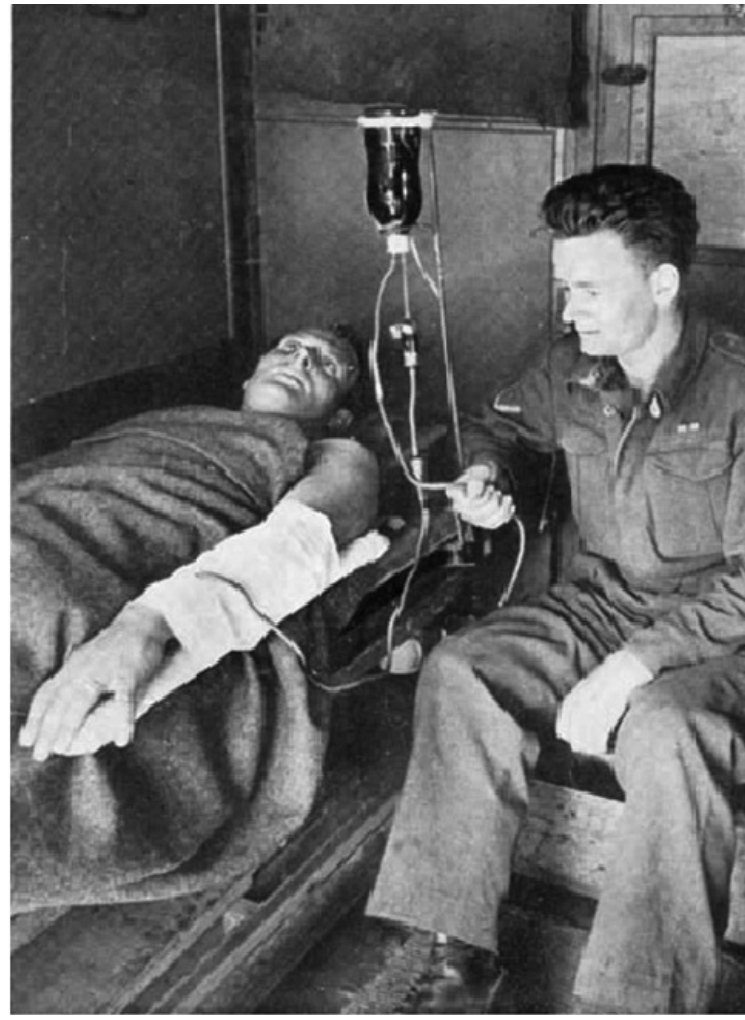

Şekil 1. II. Dünya Savaşı'nda cankurtaranda transfüzyon

enfeksiyon taramaları ve bankacılık, komplikasyonlar ve artan hasta yükü transfüzyonun maliyetini yükseltmektedir. Transfüzyonun anemiden bağımsız olarak hasta sonuçlarını kötüleştirdiğine ve doktorların transfüzyon alışkanlıkları arasındaki farklılıklara dair son yıllarda artan yayınlar dikkat çekmiştir (4-7). Örneğin, ortopedik cerrahideki transfüzyon oranları \%17-82, yoğun bakımda \%20-53, akut koroner sendromda ise \%0-28 gibi geniş bir aralık göstermektedir (8-12).

Doktorların transfüzyon alışkanlıklarının uygunluğunu inceleyen ve transfüzyon konusunda uzman 15 kişiden oluşan uluslararası bir kurulun 2011'de yayımladığı raporda ${ }^{(13)}, 494$ klinik araştırma değerlendirilmiştir. En az 2 grup hastayı karşılaştıran, gruplardan birine transfüzyon yapılan ve hemodinamik instabilite ya da aktif kanaması olmayan hastaları kapsayan bu araştırmalardan 456 farklı klinik senaryo üretilmiş, bu senaryolardaki kan kullanımının uygunluğu kurul üyelerince oylanmış ve sonuçta transfüzyonların yalnızca \%11.8'i uygun bulunurken, \%59.3'ü uygunsuz ve \%28.9'u uygunluğu belirsiz kabul edilmiştir. Yani klinik uygulamaya girmeden önce etkinlik ve güvenlik açısından ayrıntılı değerlendirmelere tabi tutulan birçok tedavi yaklaşımının aksine, kan ve kan bileşenleri transfüzyonu hastaya göre değil doktora göre değişen neredeyse keyfi bir uygulama olarak kabul edilebilir.

"Hasta Kan Yönetimi" terimi ilk olarak 2007'de kullanılmış olup, tüm bu sürecin bir sonucu olarak, transfüzyon konusuna yeni bir yaklaşım gereksinimiyle doğmuştur ${ }^{(14)}$. Transfüzyon pratiğini ürün odaklı olmaktan çıkaran ve hasta odaklı hale getiren bu yeni yaklaşım, 2010'da Dünya Sağlık Örgütü tarafından üyelerine önerilmiştir ${ }^{(15)}$. Hasta bakım kalitesinin arttırılması için uygun kan kullanımını amaçlamakta; doğru zamanda, doğru ürünü, doğru hastaya doğru nedenle vermenin yollarını aramaktadır. Maliyeti düşürerek kaynakların doğru yere kaydırılabilmesi diğer amaçlarındandır ${ }^{(16)}$.

Hasta kan yönetimi (HKY) projesinin "toplam eritrosit hacminin, kan kaybının ve hastanın fizyolojik rezervinin optimizasyonu" olmak üzere 3 temel ayağı bulunmaktadır (Şekil 2). Zamanlama olarak ise opere edilen hastalarda "preoperatif, intraoperatif ve postoperatif" olarak tanımlanan süreçler, opere edilmeyen hastalara "işlem/yatı̧ öncesi, işlem/yatış dönemi ve işlem/yatış sonrası" olarak uyarlanabilir. Temel mantığı hastanın transfüzyon riskinin belirlenmesi ve bu riski yüksek bulunan hastalarda transfüzyon olasılığının azaltılması, hatta ortadan kaldırılabilmesi için alternatif bir tedavi planının oluşturulmasıdır. Farklı hasta gruplarında yapılan birçok çalışmada, projenin hasta sonuçlarına olumlu etkileri gösterilmiştir. Aktif koroner iskemisi, devam eden kanaması, hemodinamik instabilitesi olan ve ciddi sepsis/septik şoktaki hastalar genellikle bu projenin kapsamında değildir (17).

HKY'nin ne olduğu, yöntemleri, amacı ve sonuçlarıyla ilgili yayınlar, güncel literatürde oldukça fazla olmakla birlikte, "etkin" bir HKY projesinin hastane uygulamasına tam olarak geçirilme yöntemleri konusunda yeterli bilgi ve deneyimlere dair yayınlar sık değildir. Bu tarz yerleşik bir kültür haline gelmiş uygulamalardaki değişiklikler güçlü araştırma sonuçlarına dayandırılarak hedeflense bile oldukça zor olabilir. Bilgi ve interdisipliner iletişim eksikliği, kaynak kısıtıılığı, yönetim ve siyasi otoritenin yaklaşımı, klinisyenlerin değişime direnci, kılavuzların pratik uygulamada aktif 


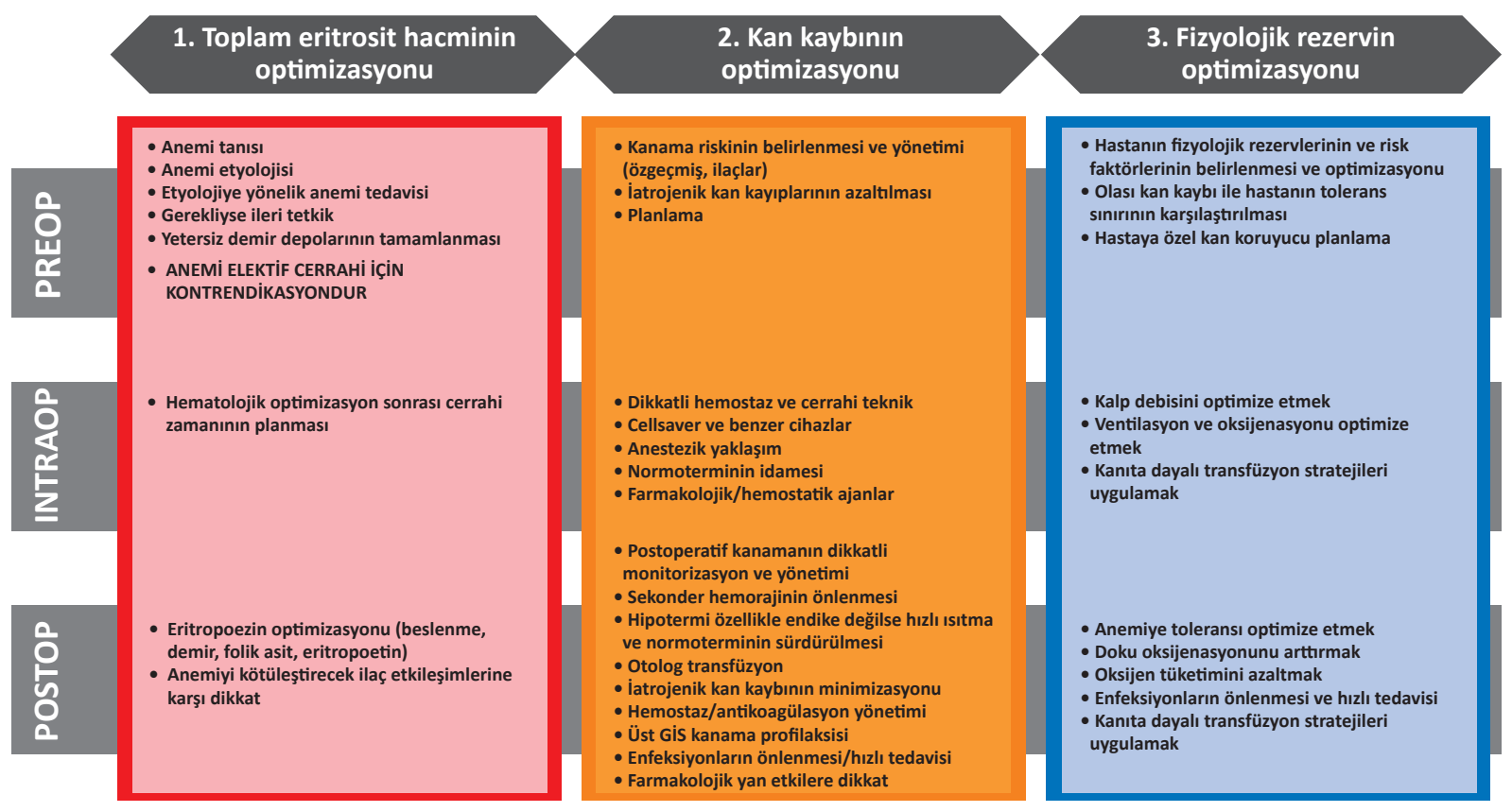

Şekil 2. Hasta kan yönetimi

kullanılma gerekliliği, hasta laboratuvar ve transfüzyon verilerini birleştirecek bilgisayar yazılımı gereksinimi HKY projesini uygulamaya geçirmenin önündeki başlıca engellerdendir. Hastanın tüm tedavi sürecini kapsaması da gerektiğinden, etkili bir HKY projesi ancak medikal, cerrahi, anestezi ve yoğun bakım kliniklerinin aktif katılımı ve iletişimi; hastane, hatta ülke sağlık sistemi yöneticilerinin desteği, yeterli finansman ve bilgisayar teknolojisinin uygun kullanımıyla sağlanabilir ${ }^{(18-20)}$.

Dünyadaki uygulama alanına baktığımızda HKY konusunda oldukça yol almış bazı ülkelerin bu köklü değişimi gerçekleştirme yöntemleri ülkemiz için de yol gösterici olabilir. Avusturalya ve Amerika Birleşik Devletleri kendi deneyim ve yöntemleriyle ilgili en çok yayında bulunan iki ülke olarak dikkat çekmektedir. "Hasta kan yönetimi nasıl etkinleştirilir?" sorusunun bu yayınlardan elde edilen yanıtı 3 başlık altında özetlenebilir; veri takibi (bilgisayar işletim sistemi), eğitim ve denetim.

\section{Veri Takibi (Bilgisayar İşletim Sistemi)}

Etkin bir veri takibi için yine etkin bir bilgisayar işletim programı kullanılmalıdır. Anemi verileri (preoperatif anemik hasta, iatrojenik anemi, tedavi edilebi- len anemi oranları, anemi etiyolojisi vb.), kan ve kan bileşenlerinin örneğin bölüm, ameliyat, doktorlara göre kullanımı, mortalite, morbidite, hastane ve yoğun bakımda kalış süreleri gibi veriler, kurulabilecek bir HKY ağıyla hastane içi, hastaneler arası, hatta doktorlar arası kıyaslama (benchmarking) verileri, maliyet analizleri gibi bilgiler bu bilgisayar programıyla kolay ulaşılabilir ve özetlenebilir hale getirilir. HKY proje uygulamasının başlangıcından yerleştirilmesine kadar geçen sürede aksaklıkların nedeni ve alanının belirlenmesi için bu veriler yol gösterici olacaktır ${ }^{(21,22) .}$

HKY yaklaşımının yerleştirilmesi sürecinde, kullanılan bilgisayar işletim programı aracılığıyla "karar destek sistemleri"nin (KDS) kullanımı da sıktır. Bilgisayar yazııımı aracılığıyla kan veya kan ürünü istemi yapılırken hastanın son laboratuvar değerleriyle ilgili birtakım uyarı kutucukları, endikasyon sorgulama (acil durumlar dışında), restriktif transfüzyon yaklaşımıyla ilgili en çok atıf alan yayınların ekrana gelmesi, tek seferde tek ünite transfüzyona yönlendirme gibi yöntemler bu sistemi oluşturabilir. Yazer ve ark.'nın ${ }^{(23)}$ yayımladığı verilere göre uyarıların ekrana gelmeye başlamasından sonraki 6 aylık dönemde uygunsuz eritrosit transfüzyon istemlerinin $\% 12$ 'si, plazma istemlerinin ise $\% 25^{\prime} \mathrm{i}$ iptal edilmiştir. Ama ilerleyen 


\section{Patient Blood Management Guidelines (Australia)}
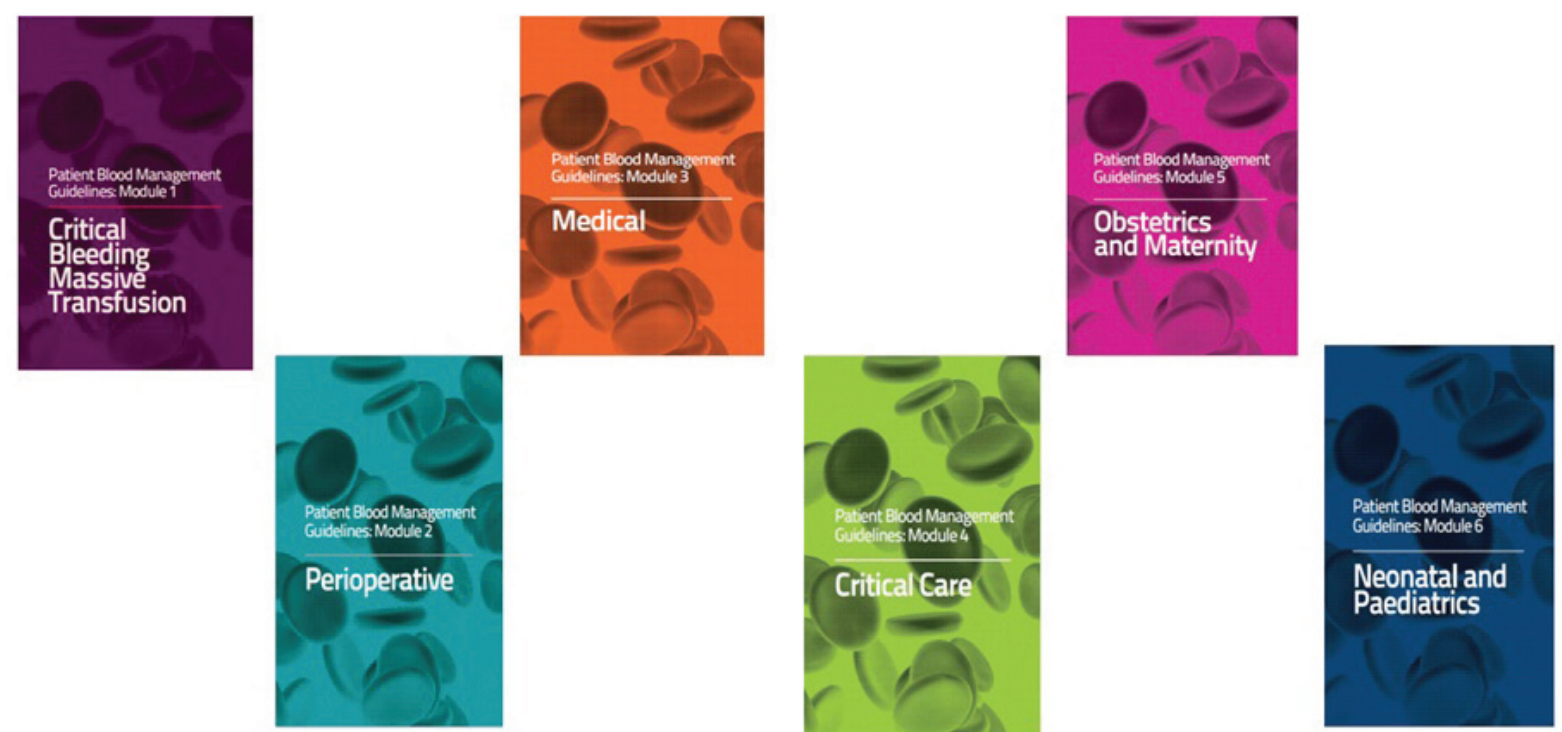

Şekil 3. Avusturalya National Blood Authority hasta kan yönetimi kılavuzları

dönemlerde daha fazla azalma görülmemiş ve transfüzyon pratiğinin optimizasyonunda eğitim gibi diğer yöntemlerin de sürekliliği önerilmiştir .

\section{Eğitim}

Yalnızca doktorları değil, yardımcı sağlık personelini de kapsayan ve didaktik olmayan interaktif eğitim ve toplantılar, tıp ve hemşirelik fakültelerinde dersler, asistanlık eğitiminde kan merkezi rotasyonları, toplumu ve sağlık çalışanlarını bilinçlendirmeye yönelik reklam, kamu spotu ve sloganlar ("Transfuse and Assess", "Why give two when one will do?" örnekleri gibi) kullanılabilir ${ }^{24,25)}$. Zuckerberg ve ark.'nın ${ }^{(26)}$ yaptığı bir çalışmada, eğitimin HKY projesini yerleştirmede oldukça etkili olduğu ve KDS'nin de kanıta dayalı uygulamalara eğitim aracılı̆̆ıla sağlanan adaptasyonu sürdürmede kullanılabileceği belirtilmiştir.

\section{Denetim}

Denetim, köklü alışkanlıkların değişiminde eğitimle beraber en etkili yöntemlerdendir. Yayınlarda denetim amacıyla elektronik posta, bilgisayar yazılımı, telefon ve doktor karneleri gibi yöntemlerden söz edilmektedir. Bu yöntemler retrospektif ya da prospektif olabilir. Örneğin, akut durumlar dışında; icapçı transfüzyon hekiminin onayı olmadan hastaya kan transfüzyonunun yapılamaması, bilgisayardan kan isteminin belli sayfaları atlayamadan (hastanın son hemoglobin değerine dair bilgilendirme, uygunsuz transfüzyon durumunda konuyla ilgili en çok atıf alan çalışmalar, transfüzyon endikasyonu hakkında ayrıntılı açıklama yapma gerekliliği vb.) doktorların aylık transfüzyon raporlarının (uygun ve uygunsuz transfüzyon oranları) karşılaştırmalı olarak kendilerine veya yöneticilerine gönderilmesi, uygunsuz transfüzyon yaptığı belirlenen doktorun belirli bir dönem sonunda bunu tartışmak üzere elektronik postayla davet edilmesi gibi yöntemler denetim yolları arasında sayılabilir ${ }^{(21,27-29)}$.

Tinmouth ve ark.'nın ${ }^{(30)}$ yayımladığı bir derlemede, kan ve kan ürünü kullanımını azaltmada kılavuz kullanımının teşviki, eğitim, anımsatmalar (bilgisayar programı veya transfüzyon formları aracılığıyla) ve denetim gibi farklı yöntemleri tek ya da çoklu şekilde kullanmış 19 çalışma incelenmiştir. Bu çalışmalardan 5 'i tek yöntemin, kalan 14'ü 1'den fazla yöntemin transfüzyon pratiğini değiştirmedeki etkinliğini değerlendirmiştir. Çalışmalardan $18^{\prime}$ inde en az 1 kan veya kan ürünü transfüzyonunda azalma belirlenirken, bir çalışmada ise uygunsuz transfüzyon oranının azaldığı saptanmıştır. Yapılan bu sistematik derlemeye göre, transfüzyon pratiğini değiştirmek amacıyla uygulanan yöntemlerin etkinliği arasında fark görülmemiştir. 
Etkin bir HKY uygulamasının ülkemiz çapında yerleştirilebilmesi için bu yöntemler kullanılabilir. Bu konuda önder olan ülkelerin deneyim ve süreçleri ise yol gösterici olacaktır. Avusturalya ve $A B D$ bu amaçla incelenebilir.

\section{AVUSTURALYA'DA HASTA KAN YÖNETIMi}

1990'da kan ve kan ürünleri transfüzyonu konusundaki değişimi başlatan Avusturalya profesyonel bir "değişimi yönetme programı" kullanmıştır. "Kotter Değişim Modeli" iş dünyası gibi farklı disiplinlerde de başarıya ulaşmış ve 1) değişim için motivasyon, 2) etkin yöneticilerin görevlendirilmesi, 3) multidisipliner ekip oluşturulması, 4) stratejiler, eğitim ve iletişim için seçilen öncüler, 5) düzenli edinilen geri dönütler gibi yöntemleri önceleyen bir modeldir (31). Avustralya Sağlık Kalite ve Güvenlik Komisyonu, HKY Projesi'ni ulusal öncelik olarak kabul etmiş ve hastane akreditasyonuna dahil etmiştir. Günümüzde artık HKY Avusturalya'da sağlıkta ulusal güvenlik ve kalite standartları arasındadır (7).

National Blood Authority (NBA), Avusturalya'nın kan ve kan bileşenleri konusundaki en yetkili kurumudur. Bu kurum internet üzerinden transfüzyon ve HKY ile ilgili birçok doküman yayımlamaktadır ${ }^{(32)}$. 2001'de yayımlanan kan ve kan ürünü odaklı kılavuzlar NBA tarafından 2011'de hasta odaklı kılavuzlarla değiştirilmiştir. Altı farklı klinik alana özelleşmiş ulusal HKY kılavuzları bulunmaktadır (Şekil 3).

NBA yayınları arasında HKY'nin içeriği, sonuçları gibi birçok yayın yanında farklı olarak bu projenin etkin hale getirilişinde kullanılabilecek yöntemleri içeren bir kılavuz da bulunmaktadır. Bu kılavuzda, projenin başarısı, 1) kanıta dayalı içeriğin kullanımı, 2) lokal kullanıma adaptasyon, 3) etkili veri toplama ve sistemleri ve geri dönüt istatistikleri, 4) özellikle anestezistlerin büyük rolünün olduğu multidisipliner ekip kurulması, 5) kanıtlar ve pratik arasındaki boşlukların belirli aralıklarla belirlenmesi, 6) sürekli eğitim ve iletişim, 7) etkili kişilerin liderliği gibi faktörlere bağlanmıştır (20).

2008'de Batı Avusturalya Sağlık Bakanlığı, tüm sağlık sistemini içeren 5 yıllık bir HKY Projesi başlatmıştır. 2017'de yayımlanan sonuçlara göre yalnızca ürün maliyeti göz önüne alındığında, 18.078 milyon
Avusturalya doları tasarruf edildiği; komplikasyonlar, personel mesaisi gibi tüm harcamalar düşünüldügünde ise tasarrufun 78-79 milyon Avusturalya dolarına ulaştığı, projenin uygulamaya geçirilmesi için ise bir defaya özgü 4.4 Avusturalya doları harcandığı bildirilmiştir. Harcamalar ulusal HKY medikal koordinatörü, ulusal HKY hemşire koordinatörü, veri toplanması ve HKY verilerinin oluşturulması gibi görevleri olan personel ücretleri, HKY proje yönetici ve elemanlarının ulusal ve uluslararası yolculukları, sağlık çalışanları ve toplumun eğitimi için kullanılmıştır. Bu 5 yıllık süreçte herhangi başka radikal bir değişiklik de yapılmadığı göz önüne alınarak, hasta sonuçlarına bakıldığında; ortalama hastanede yatış süreleri \%15, hastane enfeksiyonları \%21, MI ve inme oranları ise \%31 azalmıştır. Bu yayın dünyadaki ilk tüm ulusal sağlık sistemini kapsayan HKY projesinin sonuçlarını bildirmektedir ${ }^{(33)}$.

\section{AMERIKA BíRLEŞiK DEVLETLERI'NDE HASTA KAN YÖNETIMI}

Kan transfüzyonunun ABD'de hospitalizasyon süresince görülen en sık ortak uygulama olup, aynı zamanda gereksiz kullanımı olan ilk 5 uygulamadan biri olduğu 2012'de "The Joint Commision" tarafından yayımlanmıştır ${ }^{(34)}$. Bu verilerle hız kazanan HKY projelerinin ABD'de ulusal bir uygulaması olmamakla birlikte, birçok hastane bazında oldukça ilerleme sağlanmıştır.

Hicks ve ark.'nın ${ }^{(29)}$ yaptığı bir çalışmada, cerrahi servislerde görev yapan yardımcı sağlık personeli, asistan ve uzman doktorların da dahil olduğu tüm sağlık çalışanlarına önce transfüzyon bilgilerini ölçen bir anket, daha sonra güncel kılavuz bilgileri ve mevcut transfüzyon alışkanlıklarının bu kılavuzlara uygunluk oranlarını da kapsayan bir eğitim programı uygulanmıştır. Kliniklerin, ekiplerin ve kişilerin aylık transfüzyon raporları elektronik posta yoluyla tüm çalışanlara gönderilmiştir. Açık isimlerin yer aldığı bu raporlama sistemi başta tepkiyle karşılansa da yöneticilerin devam eden desteği ile aşılmış ve yazarlar tarafından değişimi sağlayan en etkin yöntem olduğu düşünülmüştür. Çalışma sonucunda, doğru transfüzyon oranları artmış, transfüzyon oranları ve maliyet azalmıştır.

2017'de John Hopkins Hastanesinden yayımlanan bir raporda (21) ise 2012 'de başlatılan, uygulamaya geçi- 
rilmesinde bir anestezistin başkanlığındaki "klinik komite"nin görev yaptığı HKY projesinde, öncelikle transfüzyon eşik ve hedef değerlerinden söz edilen, restriktif transfüzyon yaklaşımının liberal yaklaşıma üstünlüklerini anlatan 8 çalışmanın anlatıldığı bir eğitim kampanyası başlatılmıştır. Antifibrinolitik kullanımı, aneminin erken tanı ve tedavisi, flebotomiye bağlı iatrojenik aneminin engellenmesi için küçük laboratuvar tüplerinin kullanımı gibi yöntemler, otolog kan koruma, normoterminin korunması, otolog normovolemik hemodilüsyon gibi anestezik yaklaşımlar, topikal hemostatik ajanlar, modern koterizasyon yöntemleri, minimal invazif ve robotik cerrahi teknikler gibi HKY yaklaşımlarına da eğitim kampanyasında yer verilmiştir. Veri değerlendirme için HKY odaklı özel bir bilgisayar işletim sistemi kurulmuştur. "Klinik karar destek sistemleri" adı verilen bir sistemle, bilgisayar üzerinden kan veya kan ürünü istemlerinde hastanın son ölçülen hemoglobin değeri $7 \mathrm{~g}$ $\mathrm{dL}^{-1}$ üzerindeyse veya son 24 saate ait ölçüm yoksa kullanıcıya uyarı mesajı verilmiştir. Hemodinamik stabilitesi olmayan ve aktif kanayan hastalar dışında tek seferde bir ünite transfüzyon uyarısı da eklenmiştir. Uyarı kutucukları transfüzyon kılavuzlarına atıf yaptığından, bu şekilde eğitim programına katkıda da bulunulmuştur. Hem kliniklerin hem doktorların transfüzyon verileri grafiklerle kıyaslanarak raporlanmış ve klinik yöneticilerine gönderilmiştir. 2017 yılına ait veriler 2014 öncesiyle kıyaslandığında, transfüzyon yapılan hasta oranının \%11.3'ten \%10.4'e, kullanılan plazma oranının \%2.9'dan \%2.2'ye, trombosit oranının ise \%3.1'den \%2.7'ye gerilediği saptanmıştır. Transfüzyonların $8 \mathrm{~g} \mathrm{dL}^{-1}$ üzerindeki hemoglobin değerlerinde uygulanma oranı ise \%34.7 azalmıştır. 2014'le karşılaştırıldığında, 2017'de 2.120.273 dolar/ yıl tasarruf edilmiş ve bu HKY projesi için harcanan miktarın 4 katına denk bulunmuştur. Yine Thakkar ve ark.'nın ${ }^{(35)} 2016$ 'da yayımladıkları John Hopkins Hastanesi HKY proje sonuçlarına göre, proje öncesi ve sonrasındaki ortalama yatış süreleri, morbidite ve mortalite oranları benzer bulunmuştur.

Sonuç olarak, HKY hem maliyeti hem de mortalite ve morbidite oranlarını azaltan ve dünyanın gelişmiş ülkelerinde uygulama alanı hızla genişleyen yeni bir kan ve kan bileşeni transfüzyon yaklaşımıdır. Yerleşmiş eski transfüzyon alışkanlıklarını bu yeni yaklaşımla değiştirmek oldukça zor olmakla birlikte, etkin bir veri takibi, bunu sağlayabilecek HKY için özelleşmiş bilgisayar işletim programı, sürekli interaktif eğitimler, hem hastane hem doktor düzeyinde gerekirse açık kıyaslamaların da dâhil olduğu denetim programları yararlı olabilir. Bunun için de aktif bir transfüzyon komitesi, gerekli finansal ve yönetimsel desteği sağlayacak hastane, sağlık ve finans sistemi yöneticileri gereklidir.

Finansal Destek: Yoktur

Funding: None

\section{KAYNAKLAR}

1. Giangrande PLF. Thehistory of blood transfusion. $\mathrm{Br} \mathrm{J}$ Haem. 2000;110:758-67. https://doi.org/10.1046/j.1365-2141.2000.02139.x

2. Goodnough LT, Brecher ME, Kanter MH, AuBuchon JP. Transfusion medicine. First of two parts-bloodtransfusion. N Engl J Med. 1999;340:438-47. https://doi.org/10.1056/NEJM199902113400606

3. Boucher BA, Hannon TJ. Blood management: a primer for clinicians. Pharmacotherapy. 2007;27:1394-411. https://doi.org/10.1592/phco.27.10.1394

4. Bernard AC, Davenport DL, Chang PK, Vaughan TB, Zwischenberger JB. Intraoperative transfusion of $1 \mathrm{U}$ to $2 \mathrm{U}$ packed red blood cells is associated with increased 30-day mortality, surgical-site infection, pneumonia, andsepsis in general surgery patients. J Am Coll Surg. 2009;208:931-7. https://doi.org/10.1016/j.jamcollsurg.2008.11.019

5. Engoren M, Schwann TA, Habib RH, Neill SN, Vance JL, Likosky DS. The independent effects of anemia and transfusion on mortality after coronary artery bypass. Ann Thorac Surg. 2014;97:514-20. https://doi.org/10.1016/j.athoracsur.2013.09.019

6. Perisanidis C, Dettke $M$, Papadogeorgakis $N$, Schoppmann A, Mittlböck M, Kyzas PA. Transfusion of allogenic leukocyte-depleted packed red blood cells is associated with postoperative morbidity in patients undergoing oral and oropharyngeal cancer surgery. Oral Oncol. 2012;48:372-8 https://doi.org/10.1016/j.oraloncology.2011.11.020

7. Farmer SL, Trentino K, Hofmann A, et al. A Programmatic Approach to Patient Blood Management - Reducing Transfusions and Improving Patient outcomes. The Open Anesthesiol J. 2015;9:6-16. https://doi.org/10.2174/1874321801509010006

8. Spahn DR. Anemia and patient blood management in hip and knee surgery: a systematic review of the literature. Anesthesiology 2010;113:482-95. https://doi.org/10.1097/ALN.0b013e3181e08e97

9. Bennett-Guerrero E, Zhao Y, O'Brien SM, et al. Variation in use of blood transfusion in coronary artery bypass graft surgery. JAMA 2010;304:1568-75. https://doi.org/10.1001/jama.2010.1406

10. Acheson AG, Brookes MJ, Spahn DR. Effects of allogenic red blood cell transfusions on clinical outcomes in patients undergoing colorectal cancer surgery: a systematic review and meta-analysis. Ann Surg. 
2012;256:235-44. https://doi.org/10.1097/SLA.0b013e31825b35d5

11. Hutton B, Fergusson D, Tinmouth A, McIntyre L, Kmetic A, Hébert PC. Transfusion rates vary significantly amongst Canadian medical centres. Can J Anaesth. 2005;52:581-90. https://doi.org/10.1007/BF03015766

12. Yang $X$, Alexander KP, Chen AY, et al. The implications of blood transfusions for patients with non-ST-segment elevation acute coronary syndromes: results from the CRUSADE National Quality Improvement Initiative. J Am Coll Cardiol. 2005;46:1490-5. https://doi.org/10.1016/j.jacc.2005.06.072

13. Shander A, Fink $A$, Javidroozi $M$, et al. Appropriateness of allogeneic red blood cell transfusion: the international consensus conference on transfusion outcomes. Transfus Med Rev. 2011;25:232-46. https://doi.org/10.1016/j.tmrv.2011.02.001

14. Goodnough LT, Shander A. Blood management. Arch Pathol Lab Med. 2007;131:695-701.

15. WHA 63.12 - Availability, Safety and Quality of Blood Products. WHA resolution; Sixty-third World Health Assembly. Geneva: World Health Organization; 2010.

16. Goel R, Shi PA. Patient Blood Management. In: Shaz $\mathrm{BH}$, Hillyer CD, Gil MR, editors. Transfusion Medicine and Hemostasis (Third Edition). Elsevier, 2019. 371-8. https://doi.org/10.1016/B978-0-12-813726-0.00059-3

17. Goodnough LT, Shander A. Patient blood management. Anesthesiology. 2012;116:1367-76. https://doi.org/10.1097/ALN.0b013e318254d1a3

18. Grimshaw JM, Shirran L, Thomas R, et al. Changing provider behavior: an overview of systematic reviews of interventions. Medical Care. 2001;39:II2-45. https://doi.org/10.1097/00005650-200108002-00002

19. Kinsman L, James E, Ham J. An interdisciplinary, evidence-basedprocess of clinical pathway implementation increases pathway usage. Lippincott's case management: managing the process of patient care. 2004;9:184-96. https://doi.org/10.1097/00129234-200407000-00006

20. National Blood Authority. Patient Blood Management Guidelines implementation strategy 2013-2017. Available from: https://www.blood.gov.au/system/ files/National-Patient-Blood-Management-Strategy2017-2021-Final.pdf.

21. Frank SM, Thakkar RN, Podlasek SJ, et al. Implementing a health system-wide patient blood management program with a clinical community approach. Anesthesiology. 2017;127:754-64. https://doi.org/10.1097/ALN.0000000000001851

22. Sadana D, Pratzer A, Scher LJ, et al. Promoting highvalue practice by reducing unnecessary transfusions with a patient blood management program. JAMA Intern Med. 2018;178:116-22. https://doi.org/10.1001/jamainternmed.2017.6369

23. Yazer $\mathrm{MH}$, Waters JH. How do I implement a hospitalbased blood management program? Transfusion.
2012;52:1640-5

https://doi.org/10.1111/j.1537-2995.2011.03451.x

24. Podlasek SJ, Thakkar RN, Rotello LC, et al. Implementing a 'Why give 2 when 1 will do?' Choosing Wisely campaign. Transfusion. 2016;56:2164. https://doi.org/10.1111/trf.13664

25. Oliver JC, Griffin RL, Hannon T, Marques MB. The success of our patient blood management program depended on an institution-wide change in transfusion practices.Transfusion. 2014;54:2617-24. https://doi.org/10.1111/trf.12536

26. Zuckerberg GS, Scott AV, Wasey JO, et al. Efficacy of education followed by computerized provider order entry with clinician decision support to reduce red blood cell utilization. Transfusion. 2015;55:1628-36. https://doi.org/10.1111/trf.13003

27. Yeh DD, Naraghi L, Larentzakis A, et al. Peer-to-peer physician feedback improves adherence to blood transfusion guidelines in the surgical intensive care unit. J Trauma Acute Care Surg. 2015;79:65-70. https://doi.org/10.1097/TA.0000000000000683

28. Goodnough LT, Shieh L, HadhazyE, ChengN, Khari P, Maggio P. Improved blood utilization using real-time clinical decision support. Transfusion. 2014;54:135865. https://doi.org/10.1111/trf.12445

29. Hicks CW, Liu J, Yang WW, et al. A comprehensive Choosing Wisely quality improvement initiative reduces unnecessary transfusions in an Academic Department of Surgery. Am J Surg. 2017;214:571-6. https://doi.org/10.1016/j.amjsurg.2017.06.020

30. Tinmouth A, Macdougall L, Fergusson D, et al. Reducing the amount of blood transfused: a systematic review of behavioral interventions to change physicians' transfusion practices. Arch Intern Med. 2005;165:84552. https://doi.org/10.1001/archinte.165.8.845

31. Kotter JP, Schlesinger LA. Choosing strategies for change. Harv Bus Rev. 1979;57:106-14.

32. National Blood Authority Australia. Availablefrom: https://www.blood.gov.au/

33. Leahy MF, Hofmann A, Towler S, et al. Improved outcomes and reduced costs associated with a healthsystem-wide patient blood management program: a retrospective observational study in four major adult tertiary-care hospitals. Transfusion. 2017;57:1347-58. https://doi.org/10.1111/trf.14006

34. Proceedings from the National Summit on Overuse [Internet]. Oakbrook Terrace (IL): The Joint Commission; 2012 [cited 2016 Jun 17]. Available from: https://www. jointcommission.org/assets/1/6/national_summit_ overuse.pdf

35. Thakkar RN, Lee KH, Ness PM, et al. Relative impact of a patient blood management program on utilization of all three major blood components. Transfusion. 2016;56:2212-20. https://doi.org/10.1111/trf.13718 